PUBLIK: Jurnal Manajemen Sumber Daya Manusia, Adminsitrasi dan Pelayanan Publik Sekolah Tinggi Ilmu Administrasi Bina Taruna Gorontalo Volume VIII Nomor 1, 2021

\title{
PENGELOLAAN SUMBER DAYA MANUSIA PADA INDUSTRI KREATIF SABLON (ZEE SCREENPRINTING) KARANGANYAR DI MASA PANDEMI COVID-19
}

\author{
Sri Wijiastuti ${ }^{1}$,Zandra Dwanita Widodo ${ }^{2}$, Kurniawati Darmaningrum ${ }^{3}$ \\ Universitas Tunas Pembangunan Surakarta \\ $\underline{\text { 64sriwijiastuti@gmail.com }}{ }^{1}, \underline{\text { zandra.widodo@lecture.utp.ac.id }}{ }^{2}, \underline{\text { kurniawatid22@gmail.com }}{ }^{3}$
}

\begin{abstract}
ABSTRAK
Penelitian ini bertujuan untuk mengetahui teknis pengelolaan sumber daya manusia dari proses rekruitmen karyawan, pengembangan dan kompensasi pada masa pandemi COVID-19, sehingga dapat menjadi keunggulan yang kompetitif bagi industri kreatif sablon ZEE Screenprinting Karanganyar. Populasi dalam penelitian ini adalah seluruh karyawan industri kreatif sablon Zee Screenprinting Karanganyar dan sampel adalah pemilik usaha dan karyawan industri kreatif sablon Zee Screenprinting Karanganyar. Pendekatan kulatitatif digunakan dalam penelitian ini, dimana pendekatan kualitatif mencoba menelaah lebih lanjut fenomena dalam setting dan konteks yang natural. Penelitian ini menunjukan bahwa pengelolaan sumber daya manusia pada usaha industri kreatif sablon selama masa pandemi COVID-19 masih dilakukan secara informal, rekruitmen karyawantidak cukup dengan hanya keahlian saja tetapi harus diiringi dengan memiliki kepribadian yang baik,pengembangan melalui pelatihan karyawan tidak dilakukan secara berkesinambungan, pemberian kompensasi tidak dilakukan secara berkala.Sedangkan pemberian motivasi dari luar pribadi karyawanyang ada, sudah cukup baik.

Kata kunci: Pengelolaan Sumber Daya Manusia, Industri Kreatif Sablon, Pandemi COVID-19 ABSTRACT

This study aims to determine the technical management of human resources from the employee recruitment process, development and compensation during the COVID-19 pandemic, so that it can be a competitive advantage for the creative industry ZEE Screenprinting Karanganyar. In this study, the population is all employees of the creative industry ZEE ScreenprintingKaranganyar and the samples of this study are business owners and employees of the creative industry Zee Screenprinting Karanganyar. Qualitative approach is used in this research, where the qualitative approach tries to further examine the phenomenon in a natural setting and context. In qualitative research, researchers try to explore and understand the meaning and deeper perceptions of different existences by different people. This research shows that human resource management in the
\end{abstract}


PUBLIK: Jurnal Manajemen Sumber Daya Manusia, Adminsitrasi dan Pelayanan Publik Sekolah Tinggi Ilmu Administrasi Bina Taruna Gorontalo Volume VIII Nomor 1, 2021

creative screen printing business during the Covid-19 pandemic is still carried out informally, employee recruitment is not enough with only expertise but must be accompanied by having a good personality, development through employee training is not carried out continuously, Compensation is not provided regularly, while providing motivation from outside the personal of the existing employees is good enough.

Keywords: Human Resource Management, Creative Industry of Screen Printing, Pandemic COVID-19

\section{PENDAHULUAN}

Pandemi COVID-19 saat ini menuntut berbagai dunia usaha untuk mampu beradaptasi dengan mengutamakan kesehatan sumber daya manusia yang dimiliki untuk menunjang keberlangsungan usaha perusahaan. Manajemenperusahaan mengubah tatanan kegiatan operasional dengan senantiasa mengedepankan protokol kesehatan serta melindungi, menjaga dan menciptakan nilai sumber daya manusia. Selain hilangnya nyawa dan pendapatan yang juga bersamaan dengan pemutusan hubungan kerja petugas, pandemi juga berdampak pada penurunan daya beli masyarakat

Berbisnis pada situasi dan kondisi pandemi COVID-19 ini, menjadi peluang sekaligus tantangan tersendiri oleh pelaku bisnis industri kratif sablon, sumber daya manusia pada lingkup perusahaan merupakan salah satu faktor yang sangat penting, sebagai aset yang paling berpengaruh dalam organisasi dalam mencapai tujuan perusahaan. Tidak hanya teknologi, sebagai kompenen terpenting, juga sumber daya manusia perusahaan perlu dikelola dan dipelihara sebaik mungkin untuk tercapainya visi misi suatu perusahaan.

Sebagai proses dalam usaha untuk meningkatkan produktivitas perusahaan yang efisien dan efektif, berbagai usaha program kinerja karyawan dilakukan untuk meningkatkat kualitas organisasi dalam perusahaan. Pemberdayaan karyawan sebagai salah satu upaya menjembatani dan memotivasi karyawan untuk tetap bertanggung jawab secara pribadi dan merupakan satu usaha karyawan memperbaiki proses dalam menyelesaikan pekerjaanya yang bertujuan untuk mencapai tujuan organisasi perusahaan. Sehingga pimpinanmanajemen yang menaungi sumber daya manusia harus memiliki kemampuan teknis pebelolaan sumber daya manusia yang sudah terasah pada perusahaanya.

Tenaga kerja atau karyawan merespon lebih kreatif serta inovatif ketika diberikan kebebasan dengan tanggung jawab serta batas yang luas, dimotivasi dan diberikan dukungan aga supaya lebih berkontribusi, dan berproses membantu memperoleh kepuasan pada pekerjaan karyawan. Maka dari itu sumber daya manusia memiliki peran yang aktif dan dominan dalam seluruh rangkaian kegiatan organisasi sebagai pelaku, perencana, dan penentu untuk mewujudkan visi misi organisasi. (Iskandar, 2018). 
PUBLIK: Jurnal Manajemen Sumber Daya Manusia, Adminsitrasi dan Pelayanan Publik Sekolah Tinggi Ilmu Administrasi Bina Taruna Gorontalo Volume VIII Nomor 1, 2021

Di dalam perusahaan terdapat dua perspektif berbeda. Pertama, diwakili "bakat individu" yang terdapat di organisasi, yang di dalamnya mencakup sejauh mana anggota memiliki motivasi dan keterampilan yang diperlukan untuk melakukan sebuah pekerjaan secara efektif (Ratnasari \& SE, 2019). Individu dalam organisasi memiliki indikasi tindakan kerja berkinerja tinggi (Pakpahan, 2020), filosofi yang dibangun perusahaan juga berpengaruh dengan bakat individu didalam perusahaan (Alimudin et al., 2019) .

Penelitian ini berfokus pada industri kreatif sablon. Alasan pemilihan sektor industri kreatif sablon adalah karena sektor ini merupakan sektor yang lebih dinamis. Dalam hal ini sekotr industri kreatif sablon lebih menantang dalam berinovasi mencari sumber daya manusia yang berkualitas. Pada sisi lain, sumber daya manusia pada sektor industri kreatif perlu memiliki kemampuan khusus yang tidak diperoleh melalui jalur pendidikan tetapi diperoleh melalui pelatihan secara langsung pada saat bekerja, dan kemampuan setiap karyawan berbeda beda. Karena itu faktor sumber daya manusia di usaha kecil menjadi faktor yang krusial.Dari uraian di atas maka rumusan masalah yang akan peneliti jawab adalah bagaimana peran industri kreatif sablon terkhususnya Zee Screenprinting dalam mengelola sumber daya manusia yang unggul dalam beradaptasi dengan tatanan kehidupan baru pada saat pandemi COVID-19. Tujuan penelitian ini adalah untuk mengetahui bagaimana mengelola sumber daya manusia dari segi rekruitmen tenaga kerja, pengembangan, kompensasi pada masa pandemi COVID-19, sehingga bisa menjadi keunggulan kompetitif bagi industri kreatif sablon Zee Screenprinting Karanganyar Tujuan penelitian adalah sebagai berikut: Mengetahui pengelolaan sumber daya manusia dari segi rekruitmen, pengembangan, dan kompensasi pada industri kreatif sablon PPCPINDOPRINT di tengah pandemi COVID- 19.

\section{METODE PENELITIAN}

Pada penelitian kualitatif ini, menggunakan pendekatan latar alami natural setting sebagai sumber data langsung dimana peneliti sendiri merupakan isntrumen kunci key instrument. (Rukajat, 2018) Penelitian kualitatif berusaha menggali dan memahami pemaknaan akan kebenaran yang berbeda-beda oleh orang yang berbeda. Dalam pendekatan kualitatif salah satu jenis pendekatan yang sering digunakan adalah pendekatan studi kasus. Studi kasus merupakan strategi penelitian dimana di dalamnya peneliti menyelidiki secara cermat suatu program, peristiwa, aktivitas, proses, atau sekelompok individu. Kasus-kasus dibatasi oleh waktu dan aktivitas, dan peneliti mengumpulkan informasi secara lengkap dengan menggunakan berbagai prosedur pengumpulan data berdasarkan waktu yang telah ditentukan. Dalam pendekatan studi kasus fokus utama 
PUBLIK: Jurnal Manajemen Sumber Daya Manusia, Adminsitrasi dan Pelayanan Publik Sekolah Tinggi Ilmu Administrasi Bina Taruna Gorontalo Volume VIII Nomor 1, 2021

adalah menekankan pada pentingnya kasus pada setiap tahapan proses penelitian dan menjawab permasalahan, penelitian yang dimulai dengan kata tanya bagaimana atau mengapa (Creswell \& Poth, 2016). Mengeksplorasi fenomena yang ada di dalam perusahaan mengenai pemberdayaan karyawan pada perusahaan bisnis kreatif, jadi bagaimana perspektif dari karyawan mengenai pemberdayaan yang dilakukan diperusahaan.

Dalam penelitian kualitatif teknik pemilihan sampel atau partisipan menggunakan teknik non probablitas (Sarwono, 2006), yaitu suatu teknik pengambilan sampel atau informan yang tidak didasarkan pada rumusan statistik tetapi lebih pada pertimbangan subjektif peneliti dengan didasarkan pada jangkauan dan kedalaman masalah yang ditelitinya. Salah satu teknik sampel non-probabilitas dalam penelitian kualitatif adalah teknik purposive sampling, memulai penelitian dengan tujuan tertentu. Fokusnya adalah pada peningkatan kinerja karyawan terhadap organisasi, karena hal ini akan bermanfaat dalam banyak cara. Peningkatan kinerja karyawan akan diterjemahkan ke dalam pemberdayaan karyawan yang semuanya pasti akan menguntungkan bagi organisasi. Fokus purposive dimana unit analisis yang dipilih adalah yang dianggap sesuai olehpeneliti.Unit analisis dalam penelitian ini adalah karyawan sudah bekerja minimal 1 tahun di Perusahaan. Jumlah partisipan dalam penelitian ini adalah 14 partisipan dari 4 divisi yaitu divisi project manager, divisidesign, divisi technical drawing, divisi general dan yang bekerja dalam tim dengan alasan akan dilakukan wawancara mendalam terhadap partisipan tersebut sehingga mendapatkan informasi yang lengkap serta mendalam.

Lokasi penelitian adalah Zee Screenprinting di Karanganyar. Perusahaan bergerak dibidang industri kreatif sablon. Industri kreatif sablon ini yang kegiatan utamanya mencakup merencanakan, mendesain, memproduksi termasuk juga menghadirkan setiap jenis produk-produk yang menjadi unggulan customernya. Perusahaan ini dipilih karena terkait dengan isu mengenai perkembangan dan pertumbuhan ekonomi kreatif sehingga peneliti ingin mengetahui bagaimana upaya organisasi terhadap karyawan di dalam perusahaan industri kreatif melalui pemberdayaan karyawan. Perusahaan dipilih sebagai lokasi penelitian oleh peneliti karena pertama berkaitan dengan konsentrasi yang dipilih oleh peneliti yaitu manajemen sumber daya manusia yang dimana dalam studi tersebut mempelajari tentang sebuah organisasi atau perusahaan dan mempelajari tentang karyawan, lalu diharapkan ilmu yang sudah dipelajari dapat diterapkan secara nyata. Kedua, bagaimana fenomena mengenai pemberdayaan karyawan di industri kreatif, oleh karena itu peneliti tertarik untuk mendalami tentang fenomena tersebut. 
PUBLIK: Jurnal Manajemen Sumber Daya Manusia, Adminsitrasi dan Pelayanan Publik Sekolah Tinggi Ilmu Administrasi Bina Taruna Gorontalo Volume VIII Nomor 1, 2021

Teknik Pengumpulan data dilakukan dengan cara mengkaji data dan arsip (content analysis), wawancara mendalam (in-depth interviewing), observasi (observation). Selanjutnya dilakukan reduksi data untuk pemfokusan, penyederhanaan dan kemudian dilakukan deskripsi dalam bentuk narasi yang memungkinkan simpulan penelitian dapat dilakukan. Sedangkan, untuk menetapkan keabsahan data digunakan teknik pemeriksaan dengan empat kriteria yaitu derajat kepercayaan (credibility), keteralihan (transferability), kebergantungan (dependability), dan kepastian (confirmability). Data yang dianalisis secara kualitatif berasal dari data yang diperoleh dari berbagai sumber yaitu wawancara.

Teknik analisis data yang digunakan adalah teknik analisis data model interaktif menurut Miles dan Huberman yang terdiri atas empat tahapan (Herdiansyah, 2013)

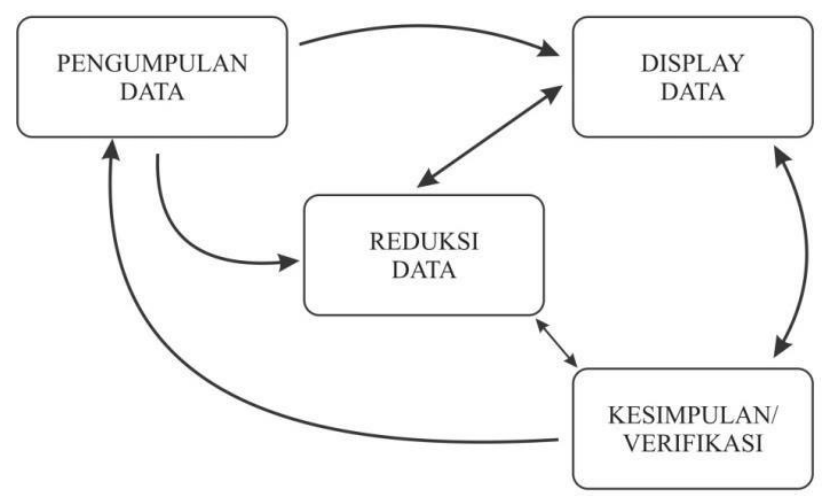

Gambar 3.1. Komponen Analisis Data Model interaktif Miles\& Huberman

Tahapan-tahapan yang harus dilakukan menurut Miles dan Huberman dalam (Herdiansyah, 2013) adalah tahap pertama adalah tahap pengumpulan data, tahap kedua adalah tahap reduksi data, tahap ketiga adalah tahap display data dan tahap keempat adalah tahap penarikan kesimpulan atau tahap verifikasi.

\section{HASIL PEMBAHASAN}

\section{Rekruitmen Tenaga Kerja}

Setelah langkah perusahaan memperkirakan jumlah tenaga kerja yang dibutuhkan, memperkirakan suplai tenaga kerja, dan melakukan analisis jabatan, maka proses manajemen sumber daya manusia selanjutnya adalah rekrutmen tenaga kerja, yaitu suatu proses untuk menemukan dan menarik calon tenaga kerja yang memiliki kualifikasi sesuai dengan lowongan pekerjaan yang ada. (Karo \& Adianto, 2017). Dalam proses rekrutmen, perusahaan dapat menggunakan dua sumber, yaitu sumber internal dan sumber eksternal. Beberapa perusahaan mempunyai kebijakan Promotion From Within, yaitu mengutamakan 
PUBLIK: Jurnal Manajemen Sumber Daya Manusia, Adminsitrasi dan Pelayanan Publik Sekolah Tinggi Ilmu Administrasi Bina Taruna Gorontalo Volume VIII Nomor 1, 2021

pengisian jabatan yang lowong dengan memprioritaskan promosi kepada karyawan internal perusahaan. Namun, sebenarnya mekanismenya tidak hanya promosi, tetapi juga rotasi dan demosi. Kalau promosi merupakan kenaikan jabatan, sedangkan rotasi adalah perpindahan jabatan pada level yang sama, dan demosi adalah penurunan jabataan. (Wijayanto \& SPi, 2013). Sedangkan sumber eksternal adalah karyawan yang akan mengisi jabatan yang lowong dilakukan dengan penarikan dari sumber-sumber tenaga kerja di luar perusahaan, seperti kantor penempatan tenaga kerja, lembaga-lembaga pendidikan, dan sumber-sumber lainnya. Beberapa metode yang digunakan dalam sumber ini antara lain: walk-in and writein (inisiatif pelamar), employee referral (rekomendasi internal organisasi), serta advertising (iklan).

Pemilik industri kreatif sablon Zee.Screenpriting juga dijelaskan dimasa pandemi Covid-19, Muhad Fatoni sebagai pemilik tidak mengutamakan pengalaman kerja dalam merekrut karyawan, tetapi lebih mengutamakan sikap terutama adab akhlak martabat dalam bekerja sama dengan Zee.Screenprinting.

\section{Pengembangan melalui training Sumber Daya Manusia}

Pelatihan (training) merupakansuatuprosesyangsistematisuntuk mengubah perilaku tertentu dari tenaga kerja agar selaras dengan pencapaian tujuan perusahaan. Pelatihan ditujukan untuk meningkatkan keahlian (skill) dan kemampuan (abilities) untuk mengerjakan tugas saat ini dan membantu tenaga kerja untuk menguasai keahlian dan kemampuan tertentu yang dibutuhkan. Sedangkan pengembangan lebih ditujukan untuk meningkatkan keahlian konseptual dan pengembangan pribadi yang dibutuhkan manajer untuk menempati jabatan yang lebih tinggi di masa mendatang. (Lolowang et al., 2016)

Muhad Fatoni, pengembangan karyawan yang sudah dilakukan di Zee.Screenprinting yaitu dengan mensuport inovasi dan kreativitas dengan anggaran yang dialokasikan untuk menambah profesionalitas karyawan baik dalam segi produksi maupun manajemen di Zee.Screenprinting.

Perusahaan harus memperhatikan skill sumber daya manusia yang dimilikinya serta kompetensi yang harus dipenuhi agar perusahan bisa stabil dan seimbang dalam strategistrategi pengembangan produknya. pengembangan adalah suatu usaha untuk meningkatkan kemampuan teknis, oretis,konseptual dan moral karyawan sesuai dengan kebutuhan pekerjaan/jabatan melalui pendidikan dan latihan. Pendidikan sendiri berhubungan dengan

peningkatan pengetahuan umum dan pemahaman atas lingkungan secara menyeluruh, (Tampubolon, 2017). 
PUBLIK: Jurnal Manajemen Sumber Daya Manusia, Adminsitrasi dan Pelayanan Publik Sekolah Tinggi Ilmu Administrasi Bina Taruna Gorontalo Volume VIII Nomor 1, 2021

\section{Kompensasi}

Kompensasi sering kali dikaitkan dengan imbal jasa dan tunjangan. Agar tenaga kerja dapat terus menerus memberikan kontribusi yang positif bagi perusahaan, tenaga kerja tersebut harus diberikan kompensasi yang sepadan atas kinerja yang telah mereka tunjukkan (Afiyah et al., 2017). Untuk jelasnya definisi kompensasi menurut beberapa ahli antara lain sebagai berikut: Drs. Malayu S.P bahwa Kompensasi adalah semua pendapatan yang berbentuk uang, barang langsung atau tidak langsung yang diterima karyawan sebagai imbalan atas jasa yang diberikan kepada perusahaan. Semantara Andrew F. Sikula mengatakan bahwa Kompensasi adalah segala sesuatu yang dikonstitusikan atau dianggap sebagai suatu balas jasa atau ekuivalen.

Dengan demikian penulis mengemukakan bahwa kompensasi merupakan pengeluaran dan biaya yang harus dikeluarkan bagi perusahaan sebagai suatu tanda terima kasih atau balas jasa kepada karyawan. Kompensasi yang diberikan oleh perusahaan kepada tenaga kerja dapat berbentuk kompensasi secara finansial maupun kompensasi nonfinansial. Kompensasi finansial yang diterima tenaga kerja dibagi lagi ke dalam dua kategori, yaitu: kompensasi finansial langsung dan kompensasi finansial tidak langsung. Kompensasi langsung ini mencakup: gaji, bonus, upah dan komisi. Sedangkan kompensasi finansial tidak langsung, dapat berupa tunjangan kesehatan, asuransi, pelaksanaan rekreasi, dan lain-lain. Adapun kompensasi non finansial itu seperti pujian, penghargaan, dan pengakuan terhadap karyawan di mana hal tersebut dapat memengaruhi motivasi, produktivitas, dan kepuasan karyawan. (Afiyah et al., 2017).

Sehingga dapat disimpulkan memang sudah seharusnya susunan kompensasi itu disusun dengan unsur-unsur yang terdiri dari kompensasi langsung dan kompensasi tidak langsung karena hal itu dapat merangsang gairah dan kepuasan kerja karyawan serta mendorong terwujudnya sasaran perusahaan.

\section{Industri Kreatif Sablon}

Sablon adalah sebuah teknik mencetak tinta diatas media berupa kaos, kaca, plastik, dan sebagainya. Sedangkan sablon kaos adalah sebuah teknik mencetak tinta diatas sebuah kaos. Ada beberapa jenis sablon yang biasa digunakan pada perusahaan konveksi yaitu jenis plastisol, discharge, superwhite, dan sebagainya. Bisnis sablon kaos merupakan bentuk usaha yang memiliki potensi dan peluang bisnis yang sangat baik. Bisnis ini akan selalu dibutuhkan karena setiap orang pasti membutuhkan sandang sebagai kebutuhan primernya. Dengan adanya bisnis sablon kaos kualitas sandang atau pakaian akan memiliki nilai lebih sehingga lebih menarik bagi setiap orang. 
PUBLIK: Jurnal Manajemen Sumber Daya Manusia, Adminsitrasi dan Pelayanan Publik Sekolah Tinggi Ilmu Administrasi Bina Taruna Gorontalo Volume VIII Nomor 1, 2021

\section{Pandemi Covid-19}

Corona Virus Disease (Covid- 19) merupakan virus yang bisa berpindah tempat dengan cepat atau menularkan menyerang dari manusia ke manusia. Covid-19 menurut WHO telah menjadi pandemi global sejak tahun 2020. Hampir seluruh dunia terguncang serta menimbulkan kekhawatiran pada semua sektor; seperti ekonomi, pendidikan, dan politik (Taufik \& Ayuningtyas, 2020) Persebaran virus corona / covid 19 telah menjadi perhatian berbagai negara. Word Health Organization (WHO) pada tanggal 11 Maret 2020 secara resmi mengumumkan peningkatan status dari epidemi ke pandemi. Penetapan status pandemi dilakukan dengan mempertimbangkan suatu penyakit yang bersifat menular dan menyebar ke banyak wilayah atau negara. COVID-19 telah menghantam UMKM sebanyak 1.785 koperasi dan 163.713 pelaku usaha mikro kecil menengah (Thaha, 2020) salah satunya adalah UMKM industri sablon, meskipun terhantam Covid-19 pengelolaan sumber daya manusia di Zee. Screenprinting masih sama dengan sebelum adanya Covid-19.

\section{KESIMPULAN}

Rekruitmen karyawan pada usaha industri kreatif sablon Zee.Screenprinting yaitu melalui perekrutan eksternal dan internal. Perekrutan eksternal oleh pemilik dilakukan dengan menggunakan media sosial, dan perekrutan internalnya pemilik lebih mengutamakan orang-orang terdekat. Dalam perekrutan karyawan pemilik rumah sablon mengedepankan karyawan yang mempunyai integritas tinggi dengan mengutamakan kebaikan adab akhlak dan martabat. Pengalaman karyawan tidak menjadi syarat utama proses rekruitmen. Pengembangan yang dilakukan pada industri kreatif usaha sablon sablon Zee.Screenprinting sangat efektif sebab pemilik memberi anggaran tersendiri untuk karyawan belajar hal-hal yang baru, berinovasi dan menambah skill mereka. Karyawan diberi target produksi untuk membiasakan posisi karyawan agar efisien dalam melakukan proses produksinya. Kompensasi yang diberikan kepada karyawan berupa paying by order dan bonus atau setelah karyawan mencapai target dalam bekerja. Kompensasi dalam bentuk cuti atau libur juga sangat efektif diberikan kepada karyawan.

\section{DAFTAR PUSTAKA}

Afiyah, S. N., Djaelani, A. Q., \& Priyono, A. A. (2017). Pengaruh Kompensasi, Lingkungan Kerja Dan Motivasi Terhadap Kepuasan Kerja Karyawan (Studi Kasus Pada Badan Pertanahan Nasional Kabupaten Malang). Jurnal Ilmiah Riset Manajemen, 6(2).

Alimudin, A., Falani, A. Z., Mudjanarko, S. W., \& Limantara, A. D. (2019). Analisis

Pengaruh Penerapan Perspektif Balanced Scorecard Terhadap Peningkatan Kinerja 
PUBLIK: Jurnal Manajemen Sumber Daya Manusia, Adminsitrasi dan Pelayanan Publik Sekolah Tinggi Ilmu Administrasi Bina Taruna Gorontalo Volume VIII Nomor 1, 2021

UMKM. EkoNiKa Jurnal Ekonomi Universitas Kadiri, 4(1), 1-17.

Creswell, J. W., \& Poth, C. N. (2016). Qualitative inquiry and research design: Choosing among five approaches. Sage publications.

Herdiansyah, H. (2013). Wawancara, observasi, dan focus groups: Sebagai instrumen penggalian data kualitatif. Jakarta: PT. Raja Grafindo Persada.

Iskandar, D. (2018). Strategi peningkatan kinerja perusahaan melalui pengelolaan sumber daya manusia dan kepuasan kerja dan dampaknya terhadap produktivitas karyawan. Jurnal Ilmiah Bisnis Dan Ekonomi Asia, 12(1), 23-31.

Karo, G. K., \& Adianto, E. (2017). Pengukuran Produktivitas Karyawan Dengan Metode Full Time Equivalent (FTE) PT. Astra International Tbk Divisi Astra Motor Penempatan Jakarta Honda Center. Journal of Industrial Engineering and Management Systems, 7(1).

Lolowang, M. G., Adolfina, A., \& Lumintang, G. (2016). Pengaruh Pelatihan dan Pengembangan Sumber Daya Manusia terhadap Kinerja Karyawan pada Pt. Berlian Kharisma Pasifik Manado. Jurnal EMBA: Jurnal Riset Ekonomi, Manajemen, Bisnis Dan Akuntansi, 4(2).

Pakpahan, A. K. (2020). Covid-19 Dan Implikasi Bagi Usaha Mikro, Kecil, Dan Menengah. Jurnal Ilmiah Hubungan Internasional, 59-64.

Ratnasari, S. L., \& SE, M. M. (2019). HUMAN CAPITAL (Manajemen Sumber Daya Manusia). Penerbit Qiara Media.

Rukajat, A. (2018). Pendekatan Penelitian Kualitatif(Qualitative Research Approach). Deepublish.

Sarwono, J. (2006). Metode penelitian kuantitatif dan kualitatif.

Tampubolon, H. (2017). The relationship between employee engagement, job motivation, and job satisfaction towards the employee performance. Corporate Ownership \& Control, 13(2), 473-477.

Thaha, A. F. (2020). Dampak covid-19 terhadap UMKM di Indonesia. BRAND Jurnal Ilmiah Manajemen Pemasaran, 2(1), 147-153.

Wijayanto, D., \& SPi, M. M. (2013). Pengantar manajemen. Gramedia Pustaka Utama. 